\title{
Towards Effective Democratic Oversight of Intelligence Services: Lessons Learned from Comparing National Practices
}

\section{Hans Born *}

There could scarcely be a more appropriate time than the present to address the issue of oversight of security and intelligence services. In the wake of the events of September 11, 2001, the Iraq war, and the bombings in Madrid on March 11, 2001, many of those responsible for overseeing intelligence in both the legislative and the executive branches of government are currently involved in investigating the intelligence services and the way political leaders use or misuse the intelligence they receive. The U.S. 9/11 Commission $^{1}$ and the U.K. Butler Commission, ${ }^{2}$ to mention just two inquiries, have dealt with formidable questions indeed: Are intelligence officials working effectively and within the rule of law? Do political leaders politicize intelligence? Do intelligence services need additional legal powers and resources in order to deal with terrorist threats? These and other questions illustrate that the process of intelligence oversight has two important goals in democratic societies: keeping the services in line with their legally defined mandate and ensuring their effectiveness. In this article the focus is on comparing legislative oversight practices in selected democratic states, with the goal of making recommendations for strengthening intelligence oversight. ${ }^{3}$ A focus on strengthening oversight is necessary because the changed security climate since $9 / 11$ has underlined the need to balance our commitments to security and democracy. This can only be achieved if the new powers that have been granted to the intelligence services are accompanied by enhanced intelligence oversight.

\section{Intelligence}

Often regarded as the second oldest profession, intelligence has become a crucial factor in a state's security and foreign policy. ${ }^{4}$ Security and intelligence services are a key component of any state, as they fulfill four essential functions: (1) to warn of surprise

* Hans Born (The Netherlands) is a Senior Fellow in democratic governance of the security sector at the Geneva Centre for the Democratic Control of Armed Forces.

1 The 9/11 Commission Report: Final Report of the National Commission on Terrorist Attack upon the United States, authorized edition (New York: W. W. Norton, 2004). Also available at http://www.9-11 commission.gov/.

2 Report of a Committee of Privy Counsellors, Review of Intelligence on Weapons of Mass Destruction (London: The Stationery Office, 14 July 2004). Also available at http://www.butlerreview.org.uk/.

3 The article is based on Hans Born and Ian Leigh, Making Intelligence Accountable: Legal Standards and Best Practice for Oversight of Intelligence Agencies (Oslo: Official publisher of the Norwegian Parliament, forthcoming, 2004); and Hans Born, Loch Johnson, and Ian Leigh, eds., Who is Watching the Spies? Establishing Intelligence Service Accountability (Dulles, VA: Brasseys, forthcoming, 2005).

4 Phillip Knigthley, The Second Oldest Profession: Spies and Spying in the Twentieth Century (New York: W.W. Norton, 1988). 
strategic threats; (2) to provide long-term expertise; (3) to support the decision-making process of policy-makers; (4) to maintain secrecy of information, requirements, sources, methods, and means. ${ }^{5}$ Especially in the post-Cold War era, which is characterized by asymmetrical threats, surprise attacks by terrorist organizations, and civil wars with dangerous and unexpected spillover effects, there is a greater need for, as Donald Rumsfeld put it, "exquisite" intelligence. ${ }^{6}$ Getting better intelligence, therefore, is essential, and should be one of the tasks of the overseers of the intelligence services in the legislative and executive branches. This necessary task is rendered more difficult by the inherent challenges of monitoring terrorist cells and networks of secret terrorist organizations, which are mobile and fluid, transforming into other shapes continuously and rapidly.

Without effective intelligence, the preemption and prevention of expected attacks from rogue states and terrorist cells are impossible. Legislators have to ensure that recommendations for improving security and intelligence services are implemented, notably: more intelligence collection through human intelligence (HUMINT) instead of relying on communication intercepts and satellite images; promoting creativity and fostering criticism instead of rewarding risk avoidance and conformity; and harmonizing policy-making and intelligence. ${ }^{7}$

In daily life, the word intelligence is used in many different ways. In a democratic society, however, it is important to limit the mandate of the intelligence services to cover only dangers and potential dangers to national security. If security and intelligence services are given functions in other aspects of daily life-e.g., public transportation, internet communication, or education - the real danger exists that too many aspects of society will become "securitized," which turns the state into a so-called security state. National security should be distinguished from regime security, which relates to the protection of a (semi-)authoritarian regime against its own people. National security, on the contrary, not only relates to the protection of the state but also to the protection of the human rights of the individual citizens of that state. ${ }^{8}$

What is intelligence? In government, intelligence usually has a restricted meaning - it has particular associations with international relations, defense, national security, and secrecy, and with specialized institutions labeled "intelligence." Intelligence

5 Mark Lowenthal, Intelligence: From Secrets to Policy (Washington, D.C.: CQ Press, 2003), $2-5$.

6 Nuclear Posture Review [excerpts], 15, available at http://www.globalsecurity.org/wmd/ library/policy/dod/npr.htm. Unfortunately, the last two Iraq wars have shown the limitations of intelligence. In the first Iraq war, American intelligence underestimated Saddam Hussein's weapons of mass destruction (WMD) programs, whereas in the second Iraq war the CIA overestimated Hussein's WMD capabilities.

7 Dennis M. Gormley, "The Limits of Intelligence: Iraq's Lessons," Survival 46:3 (Autumn 2004): 7-28.

8 Council of Europe - Venice Commission, Internal Security Services in Europe (Strasbourg: Council of Europe, 1998) (CDL-INF [1998] 6e).

9 Michael Herman, Intelligence Power in War and Peace (Cambridge: Cambridge University Press, 1996). 
can be described as a "kind of knowledge" and "activity pursued by the intelligence organization," and an intelligence organization can thus be described as "the type of organization which produces the knowledge." ${ }^{10}$ Because the functioning of intelligence services is based on a legally defined mandate and subordinated to civilian political leaders, it is important that the worlds of intelligence and policy remain close, but not too close, as this might lead to the politicization of intelligence.

\section{Politicization of Intelligence}

Intelligence is "information that meets the stated or understood needs of policy makers and has been collected, refined, and narrowed to meet those needs." ${ }^{11}$ Intelligence is obsolete if it is created too late or is not related to a government's policy agenda. Though it is important that intelligence be tailored very closely to the demands of policy makers, it is important that intelligence not be politicized, which means that intelligence reporting is shaped to support decisions that have already been made by the administration in power, or, worse, that intelligence is used against political opponents. Politicization of intelligence is likely to occur if:

- Intelligence is serving politics instead of policy-making (for example, if threat warnings are used to support a governmental campaign of fear during election periods);

- The administration is able to change intelligence reports;

- Intelligence units are set up for specific political purposes;

- Intelligence officers and their directors are political appointees or publicly affiliated to political parties;

- A system of checks and balances between the various governmental branches is lacking or poorly developed, leading to a situation in which one of the branches might dominate the intelligence services.

Intelligence officers are supposed to report to policy makers in an objective, balanced, timely, and professional manner. In order that intelligence services be capable of "speaking truth to power," the services should be insulated but not isolated from politics.

\section{Democratic Oversight of Intelligence Services}

Needless to say, national oversight practices vary greatly in terms of how much power is granted to intelligence services and how they are held accountable for their actions. Accountability for governmental actions is a key requirement in a democracy. Government officials, including intelligence employees, are required to answer to the elected representatives on the disposal of their powers and duties and must act upon

\footnotetext{
10 Sherman Kent, Strategic Intelligence for U.S. World Policy (Hamden, CT: Archon Books, 1965).

11 Lowenthal, Intelligence: From Secrets to Policy.
} 
criticisms or requests made of them. Government, including the intelligence services, has to accept responsibility for failure, incompetence, or deceit.

But how is intelligence accountability best achieved in practice in a liberal democracy, and which actors should be involved in the process? Although secrecy is a necessary condition of the intelligence services' work, intelligence in a liberal democratic state needs to work within the context of the rule of law, checks and balances, and clear lines of responsibility. Democratic accountability, therefore, identifies the propriety and determines the efficacy of the services under these parameters. Based on earlier research, a five-fold classification of state and non-state overseers most appropriately captures the different layers of intelligence accountability:

- Executive control;

- Parliamentary oversight;

- Judicial review;

- Internal control;

- Independent scrutiny.

According to this classification, the executive controls the intelligence services by giving them direction, including tasking, prioritizing, and making resources available. The legislative or parliamentary branch is also an indispensable actor, as it focuses on the oversight of the intelligence services primarily by enacting laws, examining the decisions and actions of the services, and authorizing the budget for the intelligence services. The judiciary is tasked with monitoring the use of special powers (and, if necessary, prosecuting possible malfeasance by intelligence officers). The intelligence services themselves are assigned the task of providing internal safeguards within the lines of command to prevent the (political) abuse of intelligence by staff members. Last but not least, civil society, think tanks, the media, and individual citizens restrain the functioning of the services by offering an alternative view of the appropriate tasks for the intelligence services, disclosing scandals, and by issuing complaints in cases of wrongdoing. There is, of course, no fail-safe method of ensuring intelligence accountability; however, the interdependence of all five stages in the process offers the best guarantee of a successful result.

Control and oversight are two different concepts. Arguably, control refers to the act of being in charge of the day-to-day management of the intelligence services. The responsibility for control of the intelligence services is held by the government, not by the legislature or parliament. Oversight as exercised by the legislative branch involves a lesser degree of day-to-day management of the intelligence services, but requires an equally important amount of scrutiny. There is a thin dividing line between government and parliament. Parliament exercises oversight, whereas government is tasked with control. These tasks are not the same: parliament ultimately has to decide how far their oversight should reach. 
It is important to stress that, in a democracy, no single area of government can be a "no-go" zone for parliamentarians. Today, it is not only normal but critical that parliamentarians exercise oversight over their national intelligence services.

This said, parliamentary oversight of intelligence still amounts to a rather recent development, which started in the 1970s in the United States and a few other Western European countries and has been gradually adopted by other nations in the following decades. The United Kingdom, for example, a long established democracy, only introduced parliamentary oversight of the intelligence services in the mid-1990s. Before then, Westminster remained outside the "ring of secrecy."

\section{Need for Parliamentary Oversight of the Intelligence Services}

Why is it important to include legislators in the general process of intelligence accountability? Four reasons spring to mind. First, the danger exists that intelligence may be abused by intelligence officers. In reporting on the conduct of the intelligence services, parliamentarians are providing a security check to prevent this. Second, an equally likely and often more dangerous scenario is the abuse of intelligence by the executive branch. As mentioned before, the so-called "politicization of intelligence" for partisan purposes has become a central theme following the war in Iraq in 2003, yet the danger existed previously and requires institutional safeguards. In the U.S. and the United Kingdom, many of those responsible for overseeing intelligence in both national legislative bodies are currently involved in investigating the functioning of the services as well as the conduct of political leaders responsible for tasking and directing the services. Parliamentarians are needed to guarantee a viable system of checks and balances that prevents one branch of the state from dominating. Third, legislators - the elected representatives of the people - authorize the budget for the intelligence services. As this concerns the taxpayers' money, it is, of course, important to include parliamentarians in the budget calculus. Fourth, parliament, on behalf of the people it represents, has to check whether human rights are respected both in theory and government policy, as well as in practice and the intelligence services' operations.

\section{Comparing Practices of Legislative Oversight}

As already indicated, national practices vary substantially with regard to the extent of the mandate, budget control powers, number of members, appointment and clearance procedures of the parliamentary oversight body. A previous study carried out by DCAF, the Norwegian Parliamentary Intelligence Oversight Committee, and the Human Rights Centre of the University of Durham, compared the laws and practices of parliamentary oversight bodies in eight different countries. The countries are Argentina, Canada, Norway, Poland, South Africa, South Korea, the United Kingdom, and the United States. These countries were chosen because they represent different political systems (parliamentary and presidential democracies), different phases of democratization ("new" and "old" democracies), one superpower, small and medium sized countries, as well as different geographical locations (Americas, Europe, Africa, Asia). 
Table 1: Comparison of the External and Parliamentary Oversight Bodies in the Eihgt Selected Countries. Source: Hans Born, Loch Johnson, and Ian Leigh, eds., Who is Watching the Spies? Establishing Intelligence Service Accountability (Dulles, VA: Brasseys, forthcoming, 2005).

\begin{tabular}{|c|c|c|c|}
\hline Country & $\begin{array}{l}\text { Passage of } \\
\text { First } \\
\text { Oversight } \\
\text { Legislation } \\
\end{array}$ & Mandate of Oversight Body & $\begin{array}{c}\text { Type of oversight body; \# Member- } \\
\text { ship, Clearance, Appointment of } \\
\text { Oversight Body }\end{array}$ \\
\hline $\begin{array}{c}\text { (A) } \\
\text { Argentina }\end{array}$ & 1992 & $\begin{array}{l}\text { Reviews legality and effec- } \\
\text { tiveness of the services, in- } \\
\text { cluding citizens' complaints }\end{array}$ & $\begin{array}{l}\text { Parliamentary oversight body of } \\
\text { fourteen MPs as members, ap- } \\
\text { pointed by parliament. There is } \\
\text { no security vetting }\end{array}$ \\
\hline $\begin{array}{c}\text { (B) } \\
\text { Canada }\end{array}$ & 1984 & $\begin{array}{l}\text { The SIRC checks legality and } \\
\text { efficacy of the agency }\end{array}$ & $\begin{array}{l}\text { External independent expert over- } \\
\text { sight body of max. five experts as } \\
\text { members, appointed by Prime } \\
\text { Minister. Members are under oath }\end{array}$ \\
\hline $\begin{array}{l}\text { (C) } \\
\text { Norway }\end{array}$ & 1995 & $\begin{array}{l}\text { The oversight focuses pri- } \\
\text { marily on the legality of the } \\
\text { services, including human } \\
\text { rights protection }\end{array}$ & $\begin{array}{c}\text { External expert parliamentary } \\
\text { oversight body; max. seven mem- } \\
\text { bers (non-MPs) but appointed by } \\
\text { parliament }\end{array}$ \\
\hline $\begin{array}{l}\text { (D) } \\
\text { Poland }\end{array}$ & 1995 & $\begin{array}{l}\text { Overviews legality, policy, } \\
\text { administration, and interna- } \\
\text { tional cooperation of the ser- } \\
\text { vices. Effectiveness is not } \\
\text { checked }\end{array}$ & $\begin{array}{l}\text { Parliamentary oversight body; } \\
\text { max. nine MPs as members, ap- } \\
\text { pointed by parliament. All mem- } \\
\text { bers undergo security vetting }\end{array}$ \\
\hline $\begin{array}{l}\text { (E) } \\
\text { South } \\
\text { Africa }\end{array}$ & 1994 & $\begin{array}{l}\text { Its oversight purview includes } \\
\text { legislation, activities, admini- } \\
\text { stration, financial manage- } \\
\text { ment, and expenditure of the } \\
\text { services } \\
\end{array}$ & $\begin{array}{l}\text { Parliamentary oversight body; } \\
\text { committee consists of fifteen } \\
\text { MPs, appointed by President. } \\
\text { Members are vetted }\end{array}$ \\
\hline $\begin{array}{l}(\mathbf{F}) \\
\text { South } \\
\text { Korea }\end{array}$ & 1994 & $\begin{array}{l}\text { It examines and comments on } \\
\text { legislation and effectiveness } \\
\text { of the services. It holds hear- } \\
\text { ings on individuals nominated } \\
\text { for senior positions in the NIS }\end{array}$ & $\begin{array}{l}\text { Parliamentary oversight body of } \\
\text { twelve members, put forward by } \\
\text { political parties }\end{array}$ \\
\hline $\begin{array}{c}\text { (G) } \\
\text { United } \\
\text { Kingdom }\end{array}$ & $\begin{array}{c}(1989) \\
1994\end{array}$ & $\begin{array}{l}\text { Finance, administration and } \\
\text { policy of MI5, MI6, and } \\
\text { GCHQ, with a view on effi- } \\
\text { ciency. It does not check le- } \\
\text { gality }\end{array}$ & $\begin{array}{l}\text { Parliamentary oversight body of } \\
\text { nine members drawn from both } \\
\text { Houses of Parliament, appointed } \\
\text { by the Prime Minister }\end{array}$ \\
\hline $\begin{array}{l}(\mathrm{H}) \\
\text { United } \\
\text { States }\end{array}$ & 1974 & $\begin{array}{l}\text { Reviews all intelligence agen- } \\
\text { cies. Approves top intelli- } \\
\text { gence appointments. It checks } \\
\text { both the legality and effec- } \\
\text { tiveness of the services }\end{array}$ & $\begin{array}{l}\text { Two Congressional oversight } \\
\text { committees, consisting of twenty } \\
\text { (House) and seventeen (Senate) } \\
\text { Congressmen, appointed by } \\
\text { House and Senate leaders }\end{array}$ \\
\hline
\end{tabular}




\begin{tabular}{|c|c|c|c|}
\hline $\begin{array}{c}\text { Budget Control Powers of } \\
\text { Oversight Body }\end{array}$ & Investigative Capacity & $\begin{array}{l}\text { Access to Classi- } \\
\text { fied Information }\end{array}$ & Country \\
\hline $\begin{array}{l}\text { Both scrutiny and authoriza- } \\
\text { tion powers }\end{array}$ & $\begin{array}{l}\text { Committee can initiate } \\
\text { investigation based on a } \\
\text { complaint or on conclu- } \\
\text { sions of its own work }\end{array}$ & Full access & $\begin{array}{l}\text { (A) } \\
\text { Argentina }\end{array}$ \\
\hline $\begin{array}{c}\text { SIRC has no authorization } \\
\text { powers, yet can comment on } \\
\text { CSIS's budget }\end{array}$ & $\begin{array}{l}\text { Committee decides upon } \\
\text { its own work plan }\end{array}$ & $\begin{array}{l}\text { Full access to } \\
\text { agency }\end{array}$ & $\begin{array}{c}\text { (B) } \\
\text { Canada }\end{array}$ \\
\hline No budget oversight function & $\begin{array}{l}\text { Can investigate what it } \\
\text { chooses within its } \\
\text { mandate }\end{array}$ & $\begin{array}{l}\text { Unlimited access } \\
\text { to all documents }\end{array}$ & $\begin{array}{c}\text { (C) } \\
\text { Norway }\end{array}$ \\
\hline $\begin{array}{l}\text { Commission scrutinizes the } \\
\text { services' draft budget and its } \\
\text { implementation }\end{array}$ & $\begin{array}{l}\text { Commission lacks inves- } \\
\text { tigative powers. Criticized } \\
\text { for lacking own initiatives }\end{array}$ & $\begin{array}{l}\text { Very much de- } \\
\text { pendent on the } \\
\text { discretion of the } \\
\text { services }\end{array}$ & $\begin{array}{c}\text { (D) } \\
\text { Poland }\end{array}$ \\
\hline $\begin{array}{l}\text { The Committee does not } \\
\text { oversee the intelligence ser- } \\
\text { vices' budgets per se, but it } \\
\text { purview includes financial } \\
\text { management of the services }\end{array}$ & $\begin{array}{c}\text { Committee has broad and } \\
\text { intrusive powers }\end{array}$ & $\begin{array}{l}\text { By law unlimited } \\
\text { access to infor- } \\
\text { mation except on } \\
\text { sources }\end{array}$ & $\begin{array}{c}\text { (E) } \\
\text { South } \\
\text { Africa }\end{array}$ \\
\hline $\begin{array}{c}\text { The Committee has no budg- } \\
\text { etary oversight powers }\end{array}$ & $\begin{array}{l}\text { Meager use of its investi- } \\
\text { gative powers }\end{array}$ & $\begin{array}{l}\text { Access guaranteed } \\
\text { by law; negligible } \\
\text { performance by } \\
\text { the Services to } \\
\text { grant access }\end{array}$ & $\begin{array}{l}(\mathbf{F}) \\
\text { South } \\
\text { Korea }\end{array}$ \\
\hline $\begin{array}{l}\text { Committee scrutinizes the fi- } \\
\text { nances together with the Pub- } \\
\text { lic Accounts Committee, but } \\
\text { has no authorization power }\end{array}$ & $\begin{array}{c}\text { Can investigate what it } \\
\text { chooses within its } \\
\text { mandate }\end{array}$ & $\begin{array}{l}\text { Yes; some "sensi- } \\
\text { tive" material can } \\
\text { be refused }\end{array}$ & $\begin{array}{c}\text { (G) } \\
\text { United } \\
\text { Kingdom }\end{array}$ \\
\hline $\begin{array}{c}\text { Both Oversight Committees } \\
\text { possess authorization and } \\
\text { appropriation powers }\end{array}$ & $\begin{array}{l}\text { Yes, e.g. Boland } \\
\text { Amendments }\end{array}$ & Total Access & $\begin{array}{c}\text { (H) } \\
\text { United } \\
\text { States }\end{array}$ \\
\hline
\end{tabular}


What they have in common is that they are all democracies, their parliaments have intelligence oversight committees, and their intelligence services function on a statutory basis.

Table 1 shows that parliamentary oversight committees have existed only in the last two decades, revealing that the "parliamentarization" of the oversight of intelligence services started very late both in new and old democracies. In many countries, this process started because of media exposures of scandals. ${ }^{12}$ In many Western European states, legislation was enacted because the European Court of Human Rights demanded that the use of special powers to interfere with private property and communicationpowers with a high potential for human rights abuses - should be based on the law. ${ }^{13}$ In post-dictatorial states, new laws governing the intelligence services and their oversight were enacted after a certain period of delay after the transition to democracy, as the intelligence services were often powerful tools of repression during the dictatorship and politicians still feared their power (for example, disclosing secret files on politicians).

Five major features of parliamentary intelligence oversight committees are discussed in this report: the mandate, type of committee, budget control powers, investigative powers, and access to classified information. To a large extent, these five features determine the oversight bodies' effectiveness, because they guarantee comprehensive oversight, they ensure that parliament has ownership over the oversight committee as well as major instruments of oversight, and-last but not least—-that parliament has access to classified information.

\section{Broad vs. Narrow Mandate}

The mandates of the parliamentary oversight bodies vary widely. In some countries, the oversight body has a broad mandate, which includes policy and operations as well as the legality and efficiency of the services (examples include the U.S., South Africa, Canada, and Argentina). In other countries, the intelligence services are only partially reviewed by the oversight bodies. For example:

- The Norwegian committee focuses on human rights protection;

- The U.K. committee covers all aspects except for the legality of the services' functioning;

- The Polish intelligence oversight committee does not address effectiveness of the services.

12 For example, in the U.S., oversight legislation was enacted by Congress after it became clear in January 1975 that the FBI had been (among other things) spying illegally on anti-Vietnam war protesters in the mid 1970s. See: U.S. Senate, Final Report, Select Committee to Study Governmental Operations with Respect to Intelligence Activities (The Church Commission), $94^{\text {th }}$ Cong., $2^{\text {nd }}$ Session, Rept., 94-755 (May 1976).

13 Iain Cameron, National Security and the European Convention of Human Rights (Dordrecht: Kluwer Law International, 2000). 
These oversight committees have a narrow mandate, with the risk that oversight is imperfect or fragmented across different institutions and oversight committees.

In addition to the distinction between broad and narrow mandates, the mandates of the oversight bodies can also be categorized into proactive versus reactive mandates. A proactive mandate is a mandate that allows the oversight body to veto or alter the policy or functioning of the services before the policy or operation is put into practice. For example, the U.S. Congressional Oversight Committees have the power of prior notification of covert operations. ${ }^{14}$ In the U.S. and some other countries, such as Argentina, the parliamentary oversight bodies have far-reaching budget control powers, enabling them to alter the policy priorities. Due to prior notification and authorization requirements, the parliamentary oversight body becomes co-responsible, which might hinder its oversight function due to a lack of critical distance between parliament as a controlling body and parliament as an authorizing body. Parliamentary oversight bodies with a reactive mandate (such as those in Norway, Canada, and the U.K.) do not have this problem. They check the government's policy and operations after the fact; therefore, parliament cannot be held responsible for a failure of government policy.

\section{Committee Type and the Issue of Ownership}

The sample of countries shows that two types of oversight bodies exist: external expert oversight bodies and parliamentary oversight bodies. The external oversight body exists in Norway and in Canada. These oversight bodies are staffed by experts or by individuals held in high esteem in society (former ambassadors, ministers, parliamentarians) with expertise in the field of national security and intelligence. In the Norwegian case, the members are appointed by parliament, and the committee reports to parliament. In Canada, its members are appointed by the prime minister, after consultation with parliamentary faction leaders, and the committee reports to the responsible minister, who then reports to parliament. The members of the oversight body of the other countries are parliamentarians, in some instances appointed by and reporting to parliament itself (as in the U.S. and Argentina), and in other cases appointed by and reporting to the prime minister (as in the U.K.).

Which is better - an external expert oversight body or a parliamentary oversight body? One might argue that an external expert body has the advantage of being able to devote more time and become more specialized in intelligence issues than parliamentarians can. On the other hand, a body whose members are parliamentarians might have more legitimacy, which can facilitate effective oversight.

Perhaps the most important issue is whether the parliament has total ownership of the oversight body - that is, whether parliament alone decides about the body's membership appointments, reporting requirements, and agenda. From this point of view, the oversight systems in the U.K. and Canada can be regarded as less favorable, as the

14 Except in cases of emergency, in which case the agencies can delay reporting for two days. 
prime minister censors the bodies' reports (in the U.K.) and decides about the membership appointments. ${ }^{15}$

\section{The Power of the Purse}

The power of the purse is one of parliament's most powerful tools. In liberal democracies, as a matter of principle (no taxation without representation), parliament has budgetary control, because the taxpayers' money is involved. In some of the selected countries, the oversight body does not have this power. Sometimes this is a matter of division of labor between the parliamentary intelligence oversight body and the parliamentary budget control committee or (parliamentary) independent audit offices (for instance, in Norway, the U.K., and Canada). In other countries, the parliament clearly lacks this power (e.g., in South Korea). Budgetary control requires that the parliamentary oversight body have access to all relevant classified budget documents (see below). As far as we could verify in this regard, the oversight committees of all selected countries have access to information related to classified programs and spending. An additional important issue, not mentioned in Table 1 , is the need for having independent audit offices with access to all relevant classified budget documents. Independence from the executive is normally guaranteed by having the audit office director appointed by and reporting directly to the legislative body.

\section{Investigative Powers}

Except for Poland and South Korea, the oversight bodies of the selected countries have included in their mandates the capacity to initiate inquiries. The cases of Poland and South Korea also show that having powers to investigate is not enough; the lawmakers also need to have the willingness and courage to start critical investigations and to raise their voice against the executive power. The U.S. joint committee inquiry into the events of $9 / 11$ illustrates that, once the report is delivered, it should be alerted that the executive is implementing the recommendations swiftly. At the time of writing this article, Thomas Kean and Lee Hamilton, the chairman and vice-chairman of the U.S. 9/11 Commission, have warned the U.S. President George Bush not to water down their proposals concerning the position of the new national intelligence director. ${ }^{16}$

Inquiries need to be backed up by subpoena powers. If the committee does not have the power to force citizens or civil servants to appear before the committee under oath, it could substantially hamper an effective inquiry, especially when it refers to scandalous or sensitive issues. In the selected countries, our research shows that the oversight bodies of four out of the eight countries do not have subpoena powers (Argentina, Poland, South Korea, and the United Kingdom).

15 In 2003, the Canadian government acknowledged that the current situation is undesirable, as it leads to a "democratic deficit." Therefore, the government has called upon parliament to have its own parliamentary oversight committee. See Stuart Farson, "The Delicate Balance Revisited: Parliamentary Democracy, Intelligence, and the War against Terrorism in Canada," in Who is Watching the Spies?, edited by Born, Leigh, and Johnson.

16 David Stout, "9/11 Panel Chiefs Signal Willingness to Bend," New York Times, 11 August 2004; The 9/11 Commission. 


\section{Access to Classified Information}

In order to exercise comprehensive oversight, parliament needs to have access to all relevant documents, including classified information. The oversight bodies of four out of the eight selected countries have unlimited access to classified documents. In the other four countries-Poland, South Africa, South Korea, and the United Kingdomaccess is restricted, either because the oversight body is dependent on the willingness of the executive (Poland and South Korea) or the services do not want to disclose sensitive material on sources and methods (U.K. and South Africa). In general, if parliament has limited access to classified documents, it is parliament itself who is to be blamed. The reason is that the classification of documents is based on laws enacted by parliament (so-called "official secrets acts"), and, therefore, parliament can choose to amend laws or reject laws that are too restrictive.

Noblesse oblige. If parliament has access to classified documents, it has the obligation to maintain secrecy. Some argue that parliaments do not have the ability to maintain secrecy, because parliament as an open institution is ill suited for discussing sensitive matters. Yet the practices in the selected countries have shown that hardly any leaks occur; parliamentary oversight bodies have put special infrastructure and safeguards in place to protect the secrets, and the members have to swear an oath to maintain secrecy and/or are thoroughly vetted. The issue of vetting parliamentarians turns out to be a controversial issue. In some countries, such as the U.S. and the U.K., parliamentarians reject vetting, as it would be an indication that they are subject to the executive branch and the security services, which carry out the vetting. Other countries (e.g., Norway) have elected that the vetting of the committee members be carried out by the security services, but that parliament (often the presidium) itself is empowered to decide what to do with the vetting results.

\section{Conclusions}

Having a legislature that is powerful enough to counterbalance the executive is necessary in a liberal democracy. A system of checks and balances between the legislative, executive, and judicial branches avoids the possibility that one branch of the state will dominate the other branches, leading to potential misuse of the security and intelligence services. The main functions of parliamentary oversight of intelligence are to oversee the propriety, efficacy, and legality of the services. The most important tools of parliament in pursuit of these goals are enacting laws, exercising budgetary controls, and inquiring into wrongdoing, failures, and ineffectiveness. Parliamentary oversight is embedded in the broader system of democratic accountability and security sector governance. Democratic accountability mechanisms include both procedures and institutions as well as a political culture that fosters transparency, openness, and an atmosphere that stimulates parliamentarians and other actors to watch the steps of government closely and to check the security and intelligence services critically.

Parliamentary oversight does, however, have some inherent dangers. Parliamentarians may draw the security and intelligence services into political controversy or, equally dangerous, an immature approach may lead to sensationalism, conspiracy theo- 
ries, and false accusations. The consequence might be that the public mistrusts and becomes cynical about not only the services but also the politicians who are supposed to pursue the common interest. On the other hand, parliamentarians might be unhappy with being members of the intelligence oversight committee, because most of what they come across is classified information, which they are not allowed to discuss with their constituency. Therefore, in terms of re-election, intelligence oversight might be not rewarding for a parliamentarians, because they cannot disclose their input or publicize their efforts to support specific classified intelligence policies and operations.

We may conclude that the effectiveness of parliamentary oversight is based not only on the authority (i.e., statutory powers) and ability (resources and expertise) of a given oversight body, but also on the courage or attitude of parliaments to hold the government and its services to account. 


\section{Bibliography}

Cameron, Iain. National Security and the European Convention of Human Rights. Dordrecht: Kluwer Law International, 2000.

Gormley, Dennis M.. "The Limits of Intelligence: Iraq's Lessons." Survival 43, no. 3 (2004).

Herman, Michael. Intelligence Power in War and Peace. Cambridge: Cambridge University Press, 1996.

Kent, Sherman. Strategic Intelligence for U.S. World Policy. Hamden, CT: Archon Books, 1965.

Knigthley, Phillip. The Second Oldest Profession: Spies and Spying in the Twentieth Century. New York: W.W. Norton, 1988.

Lowenthal, Mark. Intelligence: From Secrets to Policy. Washington, D.C.: CQ Press, 2003. 